\title{
Alpha Interferon in the Treatment of Hematologic Malignancies
}

MARK S. ROTH, M.D.

KENNETH A. FOON, M.D.

Ann Arbor, Michigan
From the Division of Hematology and Oncology, Department of Medicine, University of Michigan, Ann Arbor, Michigan. This work was supported in part by a National Institutes of Health Oncology Training Grant. Requests for reprints should be addressed to Dr. Kenneth A. Foon, 3119 Taubman Health Center, University of Michigan Hospitals, Ann Arbor, Michigan 48109. Manuscript submitted November 4, 1985, and accepted January 20,1986 .
The interferons are an important first member of a family of biologic response-modifiers used in treating human malignancies. Activities associated with the interferons include inhibition of viral replication, influence on cellular protein production, direct antiproliferative effects, and a variety of modulatory effects on the immune response. These regulatory functions of interferon underlie the interest in its use as an anticancer agent. Alpha interferon is the most extensively studied interferon species. Although antitumor activity has been seen both in vitro and in vivo in some solid malignancies, the most impressive responses have occurrred in the hematologic malignancies. More than 90 percent of patients with hairy cell leukemia have a sustained recovery of their peripheral blood cell counts with alpha interferon therapy. Approximately $\mathbf{5 0}$ percent of patients with low-grade nonHodgkin's lymphoma and cutaneous $T$ cell lymphoma demonstrate a response to alpha interferon. More than $\mathbf{8 0}$ percent of patients with chronic myelogenous leukemia have a response to alpha interferon, and in one study, nearly half of the patients with response had complete suppression of the Philadelphia chromosome clone on at least one examination. Ongoing clinical trials are addressing such issues as optimal dosage, duration of alpha interferon therapy, and combinations of alpha interferon with other biologic agents; chemotherapy drugs, and radiation.

Interferon was the term originally applied to a soluble factor that was recognized by its ability to induce interference against viral infection of chick chorioallantoic membrane by influenza $A$ virus [1]. It has subsequently been shown to be a family of closely related proteins and glycoproteins that, in addition to antiviral activity, are potent regulators of cellular function and structure and possess direct antiproliferative activities. These latter properties underlie the current interest in interferon as an anticancer agent.

Three major species of human interferon are recognized and designated alpha interferon, beta interferon, and gamma interferon [2] (Table I). Alpha interferon is produced by leukocytes (B cells, $T$ cells, null cells, and macrophages) upon exposure to B cell mitogens, viruses, foreign cells, or tumor cells. Beta interferon is produced by fibroblasts upon exposure to viruses or foreign nucleic acids. Gamma interferon is produced by $T$ lymphocytes upon stimulation with $T$ cell mitogens, specific antigens, or interleukin 2 [3]. By use of recombinant DNA techniques, complete nucleotide sequences for alpha, beta, and gamma interferons have been defined, and amino acid sequences have been derived.

The genes recognized to code for alpha interferon have been assigned to chromosome 9 [4]. Sixteen distinct sequences for alpha interferon have been described [4]. Each is approximately 166 amino acids 
TABLE I Interferons in Clinical Use

\begin{tabular}{|c|c|c|c|c|}
\hline Type & $\begin{array}{c}\text { Sublype* } \\
\text { (new nomenclature) }\end{array}$ & Source & $\begin{array}{c}\text { Purity } \\
\text { (percent) }\end{array}$ & Amino Acid Differences \\
\hline \multirow[t]{6}{*}{ Alpha } & $\begin{array}{l}\text { Leukocyte } \\
\quad(\text { IFN-alpha [LE]) }\end{array}$ & Leukocytes from normal blood & $<1^{\dagger}$ & \\
\hline & $\begin{array}{l}\text { Lymphoblastoid } \\
\text { (IFN-alpha-N1) } \\
\text { Wellferon (Burroughs Wellcome) }\end{array}$ & $\begin{array}{l}\text { Lymphoblastoid (Namalva) cells } \\
\text { in culture }\end{array}$ & $<1^{\dagger}$ & . \\
\hline & $\begin{array}{l}\text { Recombinant alpha-2 } \\
\text { (IFN-alpha-2b) } \\
\text { Intron-A (Schering) }\end{array}$ & Transformed E. coli & $>95$ & $\begin{array}{l}\text { Arginine at position } 23 \text {, } \\
\text { deletion at position } 44 \text { when } \\
\text { compared with other alpha subtypes }\end{array}$ \\
\hline & $\begin{array}{l}\text { Recombinant alpha-A } \\
\text { (IFN-alpha-2a) } \\
\text { Roferon-A (Hoffman-La Roche) }\end{array}$ & Transformed E. coli & $>95$ & $\begin{array}{l}\text { Lysine at position } 23 \\
\text { deletion at position } 44\end{array}$ \\
\hline & $\begin{array}{l}\text { Recombinant alpha-D } \\
\text { (IFN-alpha-D) }\end{array}$ & Transformed E. coli & $>95$ & 29 variations from alpha- $A$ \\
\hline & $\begin{array}{l}\text { Recombinant alpha-2 arg } \\
\text { (IFN-alpha-2c) }\end{array}$ & Transformed E. coli & $>95$ & $\begin{array}{l}\text { Arginine at position } 23, \\
\quad \text { arginine at position } 34\end{array}$ \\
\hline \multirow[t]{3}{*}{ Beta } & $\begin{array}{l}\text { Fibroblast } \\
\text { (IFN-beta) }\end{array}$ & $\begin{array}{l}\text { Fetal foreskin fibroblast } \\
\text { in culture }\end{array}$ & $<1^{\dagger}$ & \\
\hline & $\begin{array}{l}\text { Recombinant beta cys } \\
\text { (rIFN-beta cys) }\end{array}$ & Transformed E. coli & $>95$ & Cysteine at position 17 \\
\hline & $\begin{array}{l}\text { Recombinant beta ser } \\
\quad \text { (rIFN-beta ser) }\end{array}$ & Transformed E. coli & $>95$ & Serine at position 17 \\
\hline \multirow[t]{2}{*}{ Gamma } & $\begin{array}{l}\text { Immune } \\
\quad \text { (IFN-gamma) }\end{array}$ & T lymphocytes from normal blood & $<1^{\dagger}$ & \\
\hline & $\begin{array}{l}\text { Recombinant gamma } \\
\text { (rIFN-gamma) }\end{array}$ & Transformed E. coli & $>95$ & \\
\hline
\end{tabular}

* New nomenclature was proposed at a joint meeting of the World Health Organization and USAN council in May 1985.

$\dagger$ These crude preparations can be purified to near homogeneity (see text).

in length with an additional 20 amino acid secretory peptide present on the amino-terminal end. The human genes differ by approximately 10 percent in nucleotide sequence and 15 to 20 percent in amino acid sequence [5]. Two recombinant human interferons, alpha $A$ and alpha $D$, make up more than 60 percent of interferons present after buffy coat stimulation and have been extensively studied [6]. Although they possess different antiviral and antiproliferative activity in vitro, similar in vivo effects on immune effector cells have been observed [6]. The alpha interferon used in the first human clinical trials was obtained from Sendai virus-stimulated buffy coat leukocytes and represented 1 percent purity $\left(10^{6}\right.$ units $/ \mathrm{mg}$ protein) $^{*}[7]$. Refinement in purification methods by use of high-performance liquid chromatography, two-dimensional polyacrylamide gel electrophoresis, and immunoaffinity chromatography has allowed purification to homogeneity $\left(10^{8}\right.$ units $/ \mathrm{mg}$ protein) [8-10]. The use of recombinant DNA techniques with splicing of the alpha interferon gene into Escherichia coli has further allowed for pure single-species alpha interferon in larger quantities.

Unlike alpha interferon, only a single protein species has been identified for both beta and gamma interferon

\footnotetext{
* One unit of interferon is roughly the amount that reduces viral replication in tissue culture by half.
}

[5]. Beta interferon consists of 166 amino acids with 45 percent homology of nucleotides and 29 percent amino acids compared with alpha interferon [5]. Gamma interferon consists of 146 amino acids and has approximately 12 percent amino acid sequence homology compared with alpha interferon [11]. Gamma interferon may exist in biologic fluids in a dimeric form [12].

Industrial-scale production of beta and gamma interferon has only recently been accomplished, and clinical trials are limited in number. Alpha interferon, however, has been extensively studied for the past decade in both basic science and clinical research, and it is among the most potent biologic agents ever administered to man. Although antitumor activity has been seen both in vitro and in vivo in some solid malignancies (breast cancer, renal cell cancer, Kaposi's sarcoma, bladder cancer, ovarian cancer, and melanoma) $[13,14]$, the most impressive responses have occurred in the hematologic malignancies. A review of these results and proposed mechanisms of action are presented.

\section{CLINICAL EXPERIENCE}

A summary of clinical trials using alpha interferon for the hematologic malignancies is presented in Table II. Some reported trials have used highly purified preparations $\left(10^{8}\right.$ units/mg protein), whereas others have used crude preparations of alpha interferon $\left(10^{6} \mathrm{units} / \mathrm{mg}\right.$ protein). Impuri- 


\begin{tabular}{|c|c|c|c|c|c|c|}
\hline Reference & Tumor & $\begin{array}{c}\text { Number of } \\
\text { Evaluable } \\
\text { Patients }\end{array}$ & Complete & $\frac{\text { Response Rates }}{\text { Partial }}$ & Minor & $\begin{array}{c}\text { Percent } \\
\text { Tolal } \\
\text { Response* }\end{array}$ \\
\hline$[18-27]$ & $\begin{array}{l}\text { Hairy cell leukemia }{ }^{\dagger} \\
\text { Non-Hodgkin's lymphoma }\end{array}$ & 158 & 22 & 86 & 44 & 96 \\
\hline$[28-35]$ & Low-grade & 92 & 9 & 30 & 6 & 42 \\
\hline$[29,31,33,35,36]$ & Intermediate- and high-grade & 36 & 1 & 4 & 2 & 14 \\
\hline$[33]$ & Hodgkin's disease & 8 & 0 & 0 & 2 & 0 \\
\hline$[37,38]$ & Cutaneous $T$ cell lymphoma & 20 & 2 & 7 & 2 & 45 \\
\hline$[35,40-44]$ & Chronic lymphocytic leukemia & 67 & 0 & 12 & & 18 \\
\hline$[35,46-53]$ & Multiple myeloma & 224 & 3 & 41 & & 20 \\
\hline$[56-58]$ & Chronic myelogenous leukemia & 68 & 8 & 40 & 7 & 81 \\
\hline$[59]$ & Essential thrombocythemia & 4 & 3 & 0 & & 75 \\
\hline$[60-64]$ & Acute leukemia & 62 & 0 & $19^{\S}$ & & 31 \\
\hline
\end{tabular}

* Percent total response $=$ complete responses + partial responses $\div$ number of evaluable patients.

$\dagger$ Complete response means absence of hairy cells in the bone marrow and normalization of peripheral blood white cells, platelets, and erythrocytes. Partial response means a normalization of peripheral blood white cells, platelets, and erythrocyte counts and greater than 50 percent reduction in hairy cells in the bone marrow. Minor response generally means improvement in hemoglobin to more than $10 \mathrm{~g} / \mathrm{dl}$ or improvement in platelets to more than $100,000 \mathrm{cells} / \mu \mathrm{l}$ or improvement in neutrophils to more than $1,000 \mathrm{cells} / \mu \mathrm{l}$. Percent total response for hairy cell leukemia includes minor responses.

‡ Complete response and partial response not available from all trials, percent total response includes all responses.

$\S$ Most responses were of short duration.

ties in the latter include albumin, transferrin, and additional lymphokines. Despite these contaminants, the toxicities and antitumor responses seen with both preparations have been similar. The major side effects have involved a flu-like illness (fever, chills, muscle aches, headache, gastrointestinal upset, and fatigue). The onset of fever is generally four to eight hours after administration with a duration of approximately 12 hours. With repeated administration, tachyphylaxis to fever usually occurs, but fatigue and anorexia increase with dosage and duration of treatment and remain the usual dose-limiting toxicities. Other reported side effects include dose-related myelosuppression, elevated transaminase concentrations, paresthesias, anosmia, somnolence, confusion, and impotence in men. One occurrence of interstitial nephritis has been reported [15], and elevation of hepatic transaminase levels was the dose-limiting toxicity in another study [16]. All of these toxicities are reversible with cessation of drug.

\section{HAIRY CELL LEUKEMIA}

Hairy cell leukemia is a well-characterized lymphoproliferative disorder in which cells with lymphoid morphology and villous cytoplasmic projections infiltrate the bone marrow, blood, and reticuloendothelial system. It is of B cell origin and usually presents with cytopenias [17]. The disease is often indolent, with a median age of onset 50 years and a 5:1 male-to-female ratio. Standard initial therapy is splenectomy, which often restores hematologic parameters to normal; however, most of these patients have a relapse weeks to years after splenectomy. Treatment of relapses has been generally poor with standard cytotoxic agents. Excellent responses were reported [18] in seven patients with hairy cell leukemia (three complete and four partial responses) treated with crude alpha interferon. Similar data have been reported by a number of investigators using recombinant alpha interferon. $R e-$ sponse rates have been comparable with recombinant preparations after therapy thiree times a week or daily with dosages ranging from 3 to $6 \times 10^{6}$ units intramuscularly or subcutaneously [18-27]. Although the initial report suggested that complete responses were frequent, this has not been confirmed (of 158 responses reported, only 22 were complete) [18-27]. More important, however, is that virtually all of the patients with response demonstrated normalization of peripheral blood cell counts, which was maintained while they were receiving interferon therapy. Many of these patients had no prior therapy, including splenectomy. In patients with response, disease has not been reported to become refractory to alpha interferon; many patients have been followed for more than three years. In addition, improvement in natural killer activity and immunologic surface markers parallels the hematologic recovery [24]. In a recent study [20], interferon treatment was discontinued in 25 patients after 12 months of treatment. In eight of the 25 patients, a relapse occurred at a median of six months after cessation of treatment and resulted in reinduction of remission in five of the eight patients who have completed three months of therapy. Studies to assess low-dose ( 3 to $4 \times 10^{6}$ units) compared with ultra-low-dose $\left(0.3\right.$ to $0.4 \times 10^{6}$ units $)$ alpha interferon are currently underway. Phase III trials in which patients with newly diagnosed hairy cell leukemia are randomly assigned to undergo splenectomy or receive 
alpha interferon treatment are also underway. Although hairy cell leukemia accounts for fewer than 2 percent of all cases of leukemia, its response to alpha interferon makes it an ideal disease to study the putative mechanisms of activity that are addressed next.

\section{NON-HODGKIN'S LYMPHOMA AND HODGKIN'S DISEASE}

The histologic classification of non-Hodgkin's lymphoma was recently reformulated from the commonly used Rappaport system. On the basis of prognosis and morphology, the histologic types of malignant lymphoma have been grouped into low-, intermediate-, and high-grade malignancy under the Working Formulation [28]. Although many chemotherapy agents produce responses, lowgrade non-Hodgkin's lymphoma is not curable with currently available treatment. This, in combination with the indolent nature of the disease, leads to multiple episodes of treatment and relapse; eventually the patient dies from unrelated causes, toxicity of therapy, progressive disease, or emergence of a more aggressive histologic subtype. The low-grade non-Hodgkin's lymphoma have shown responses to alpha interferon [29-35]. Early results with crude alpha interferon preparations reported responses to alpha interferon in four of seven patients $[29,30]$. In the largest series reported to date [31], previously treated patients received recombinant leukocyte alpha interferon at a dose of $50 \times 10^{6}$ units $/ \mathrm{m}^{2}$ of body surface area intramuscularly three times a week. Thirteen responses were obtained (four complete and nine partial responses) among 24 evaluable patients, with a median duration of response of eight months. Alpha interferon in combination with standard cytotoxic agents is currently under investigation as first-line therapy.

Alpha interferon has shown less effectiveness in the intermediate- and high-grade lymphomas. Thirty-six patients have been treated with both crude and recombinant alpha interferon, and five responses were reported $[29,31,33,35,36]$. Further study of alpha interferon in unfavorable non-Hodgkin's lymphoma may be warranted to establish which patient subgroups might benefit from treatment.

Eight patients with advanced refractory Hodgkin's disease have been treated with crude alpha interferon [33]. Only two brief minor responses were reported. In a recent study, however, with recombinant alpha interferon, approximately 30 percent of patients with advanced refractory Hodgkin's disease have shown response (E. Bonnem, personal communication).

\section{CUTANEOUS T CELL LYMPHOMA}

Cutaneous T cell lymphoma (mycosis fungoides and the Sézary syndrome) is a non-Hodgkin's lymphoma characterized by a malignant proliferation of mature helper $T$ lymphocytes that presents with skin infiltration and an indolent clinical course. Effective therapies include topical mechlorethamine, psoralen plus ultraviolet light, total skin electron-beam irradiation, and systemic chemotherapy. Unfortunately, prolonged disease-free survival has been reported only rarely with these therapies, and the best response rates for advanced disease are reported to be about 25 percent with short duration of response [37]. Responses in nine of 20 patients (two complete and seven partial) with advanced stages of disease refractory to prior therapy were observed [38] using recombinant alpha interferon at an intramuscular dosage of $50 \times 10^{6}$ units $/ \mathrm{m}^{2}$ body surface area three times a week. Responses, defined as at least a 50 percent decrease in the sum of perpendicular measurements of malignant lesions lasting at least one month, occurred within four weeks of therapy and lasted three months to more than 25 months. Extracutaneous responses also occurred. A decrease in the size of large lesions by more than 90 percent occurred in a number of patients, suggesting that alpha interferon is the best single agent for cutaneous $T$ cell lymphoma.

\section{CHRONIC LYMPHOCYTIC LEUKEMIA}

Chronic lymphocytic leukemia is a hematologic malignancy characterized by proliferation and accumulation of relatively mature-appearing lymphocytes. Most patients have a clonal proliferation of B lymphocytes [39]. Chronic lymphocytic leukemia typically occurs in persons over 50 years (median age 60 years) and affects men more than women at a ratlo of 2:1 [39]. The disease is usually stable over months to years, but transformation to a more aggressive disease state does occur. Alkylating agents, radiation therapy, and corticosteroids are commonly used to treat patients, although few data show that survival is substantially improved. In a number of early studies crude alpha interferon preparations were reported to be effective in patients with advanced chronic lymphocytic leukemia $[35,40,41]$. In a phase II trial of recombinant alpha interferon, 18 patients were treated with both high-dose $\left(50 \times 10^{6}\right.$ units $/ \mathrm{m}^{2}$ intramuscularly) and low-dose $(5 \times$ $10^{6}$ units $/ \mathrm{m}^{2}$ intramuscularly) recombinant alpha interferon three times a week [42]; only two brief responses were reported. Five patients appeared to have an acceleration of disease while receiving recombinant alpha interferon. This low response rate was confirmed by a number of investigators $[32,33,41,43,44]$. It is in marked contrast to responses in patients with chemotherapyrefractory low-grade non-Hodgkin's lymphoma and hairy cell leukemia as previously described, and the possible mechanism for this will be addressed.

\section{MULTIPLE MYELOMA}

Multiple myeloma is a disease of uncontrolled proliferation of malignant plasma cells in the marrow; it manifests clinically by tumor formation, osteolysis, hemopolesis, hypogammaglobulinemia with a paraprotein monoclonal 
spike, and renal disease. The mean age at the time of diagnosis is 62 years. Multiple myeloma responds initially to a variety of chemotherapeutic agents; however, once it becomes refractory to first-line therapy, further responses are difficult [45]. A number of trials with crude and recombinant alpha interferon in patients with multiple myeloma have been reported [46-53]. In a pilot study, four previously untreated patients were treated daily with crude alpha interferon $\left(3 \times 10^{6}\right.$ units intramuscularly). All patients demonstrated durable responses (two complete and two partial) lasting three to 19 months [46]. This study was extended into a prospective randomized trial comparing crude alpha interferon $\left(3 \times 10^{6}\right.$ units intramuscularly daily) with melphalan/prednisone on a six-week schedule. Fifty-three patients were allotted to melphalan/prednisone and 62 patients to alpha interferon treatment. Total response rate was higher in the melphalan/prednisone group ( 41 percent) than in the interferon group (14 percent) $(p<0.05)$ (response defined as a greater than 50 percent decrease in paraprotein) [47].

Recombinant alpha interferon has been administered in a number of trials [49-53]. Dosages ranged from $2 \times 10^{6}$ units $/ \mathrm{m}^{2}$ to $100 \times 10^{6}$ units $/ \mathrm{m}^{2}$ daily. Only 22 of 122 previously treated patients had responses, compared with seven of 19 untreated patients. Of note is a recent observation of synergy between alpha interferon and high-dose chlorambucil in patients with refractory myeloma [54]. Further trials of combination alkylating agent and interferon are ongoing.

\section{CHRONIC MYELOGENOUS LEUKEMIA}

Chronic myelogenous leukemia is a neoplastic disease characterized by clonal proliferation of a myeloid stem cell. A unique chromosomal translocation, the Philadelphia chromosome, is present in about 90 percent of patients. The peak age of onset is 40 years. The clinical manifestation of the disease relates to accumulation of large numbers of immature and mature granulocytic cells in the blood and abdominal viscera. In most patients, the proliferation of the hematopoetic cells can be suppressed for one to four years with cytotoxic agents, but acute leukemia or a blast crisis develops in more than 80 percent of patients [55]. In the acute phase, therapeutic agents including those useful in the treatment of acute leukemia are ineffective. Fifty-one patients with chronic myelogenous leukemia were treated with 3 to $9 \times 10^{6}$ units daily of crude ( $10^{6}$ units $/ \mathrm{mg}$ protein) alpha interferon intramuscularly [56]. Forty-one of the patients demonstrated response to therapy, with complete (36 patients) or partial response (five patients) in the peripheral blood. Patients with response showed a gradual decrease of spleen size to normal and decrease in bone marrow cellularity. Suppression of the Philadelphia chromosome occurred in varying degrees in 20 of 51 patients and was complete in two patients. Successful lowering of platelet counts in nine patients (all previously treated) with severe symptomatic thrombocytosis has also been demonstrated [57] with crude alpha interferon. A recent study using $5 X$ $10^{6}$ units $/ \mathrm{m}^{2}$ of recombinant alpha interferon daily demonstrated 13 hematologic remissions and one partial hematologic remission among 17 patients [58]. In six of the patients with hematologic remission, there was complete suppression of the Philadelphia clone on at least one examination. Although these are very exciting data, they are preliminary and require confirmation.

\section{ESSENTIAL THROMBOCYTHEMIA}

Essential thrombocythemia is a myeloproliferative disease defined by a platelet count generally in excess of $10^{6} / \mu \mathrm{l}$, megakaryocyte hyperplasia in bone marrow, and absence of a predisposing cause (i.e., Philadelphia chromosome, increased red cell mass, infection, or iron deficiency). Essential thrombocythemia usually appears between the ages of 50 and 70 years. The major morbidity of the disease is bleeding and thrombosis with a 50 percent 5-year survival rate. Several agents ( ${ }^{32} \mathrm{P}$, L-phenylalanine mustard, busulfan, uracil mustard, and hydroxyurea) have been effective in lowering platelet counts. Recombinant alpha interferon has been administered to four previously untreated patients with essential thrombocythemia at a daily dosage of 5 to $10 \times 10^{6}$ units intramuscularly for 30 days [59]. Platelet counts returned to normal in three of the four patients. Maintenance alpha interferon therapy twice a week was given after 30 days, and patients were followed for up to 80 days without relapse. Because no known leukemogenic potential exists for alpha interferon, it may become a useful initial treatment of essential thrombocythemia.

\section{ACUTE LEUKEMIA}

Acute leukemia is a malignant stem cell disorder characterized by uncontrolled growth of poorly differentiated lymphoblasts. Early studies with crude alpha interferon were reported to produce responses in six of seven patients with acute lymphoblastic leukemia and two of three with acute nonlymphoblastic leukemia at daily dosages of 0.5 to $5 \times 10^{6}$ units $/ \mathrm{kg}$ intravenously for two weeks to two months. In phase I and II trials [62,63], 53 patients were treated with partially pure lymphoblastoid alpha interferon $\left(5\right.$ to $200 \times 10^{6}$ units $/ \mathrm{m}^{2}$ daily for 10 days). Five of 33 patients with leukemia experienced significant ( 80 to 99 percent) decreases in circulating blast counts, but bone marrow pathologic studies revealed only three patients with any degree of improvement in bone marrow infiltration (two transiently and one for three months). Recombinant alpha interferon (25 to $100 \times 10^{6}$ units daily for seven days) was administered to 13 heavily pretreated patients with only two minimal responses [64]. Alpha interferon in high doses has had limited effectiveness for management of patients with acute leukemia. The role of lower dose alpha interferon has yet to be determined. 


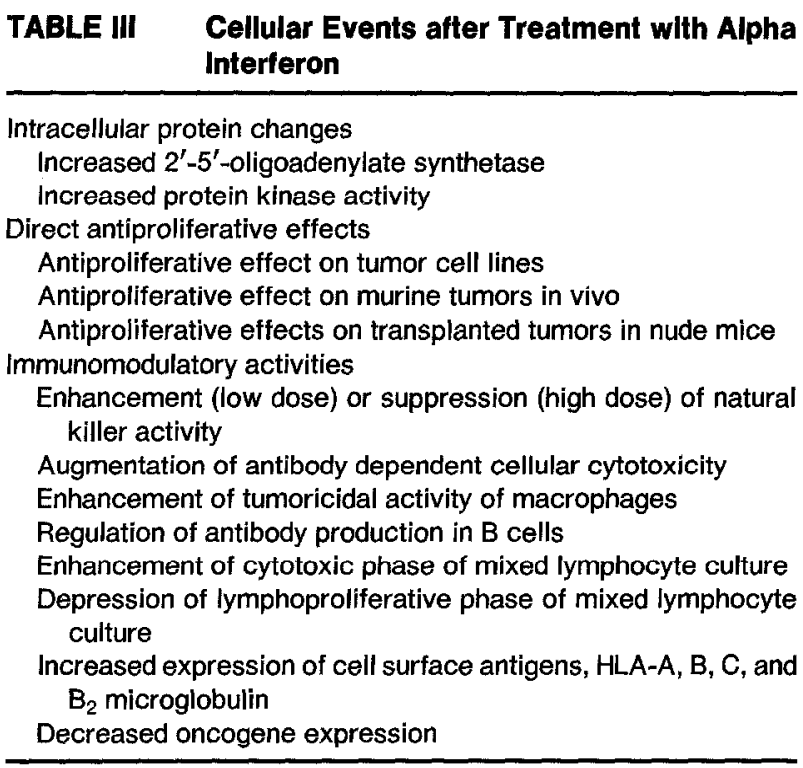

\section{MODE OF ACTION}

The effect of interferon at the cellular level is initiated by binding of the interferon molecule to a cell surface membrane receptor [65]. Competitive binding studies indicate that alpha and beta interferon interact with one cell surface receptor, whereas gamma interferon may interact with another receptor [65]. After binding to the cell surface membrane, human interferon is rapidly internalized and degraded [66]. Whether this internalization is required for the biologic responses to interferon has not been resolved. Similar to several polypeptide hormones and their target cells, a down-regulation of interferon receptors after exposure of cells to interferon occurs [66].

Direct and indirect mechanisms of the anticancer activity of interferon probably result from a number of different mechanisms, including induction of several intracellular proteins, enhancement of immune effector cells, and changes in cellular surface structure (Table III). Two enzymes appear to play a major role in interferon activity. Treatment of cells in culture with interferon results in an increase in $2^{\prime}-5^{\prime}$-oligoadenylate synthetase $[67,68]$; studies suggest that this response represents the induction of a gene that is subject to control by interferon [69]. $2^{\prime}-5^{\prime}-$ oligoadenylate synthetase is capable of synthesizing a novel series of oligonucleotides, $2^{\prime}-5^{\prime}$-oligoadenylates, in the presence of double-stranded RNA and ATP. These oligonucleotides range from 2 to 15 in length and are collectively referred to as $2^{\prime}-5^{\prime} \mathrm{A} .2^{\prime}-5^{\prime} \mathrm{A}$ in turn activates a latent endoribonuclease that is capable of cleaving both viral and host RNA (messenger RNA and ribosomal RNA) effectively inhibiting transcription and translation [65]. 2'$5^{\prime} \mathrm{A}$ introduced into normal and neoplastic cells appears to inhibit both protein and DNA synthesis [70]. The second enzyme activated by exposure of cells to interferon is a protein kinase capable of phosphorylating peptide eukaryotic initiation factor (elF-2 alpha) and ribosome-associated protein $P_{1}[65,71]$. Recent observations suggest that the interferon-induced protein kinase is protein $P_{1}[71]$. The net result of the kinase activation is the inhibition of peptide chain initiation. The exact role of these observations in relation to anticancer activity remains undetermined. Preliminary data exist correlating the levels of induced $2^{\prime}-5^{\prime}$-oligoadenylate synthetase with alpha interferon administration [72]; however, correlation with antitumor activity has not been made [73].

\section{ANTIPROLIFERATIVE EFFECT}

Alpha interferon has antiproliferative effect on some malignant tumor cells. Dose-dependent in vitro inhibition of hematologic cell lines using alpha interferon has been shown in Burkitt's lymphoma, lymphocytic lymphoma, acute myelogenous leukemia, chronic myelogenous leukemia, chronic lymphocytic leukemia, and multiple myeloma [74-78]. Interestingly, in comparative antiproliferative studies, alpha interferon has shown a greater inhibitory effect in cells of hematopoietic origin than either beta or gamma interferon, using both crude and recombinant interferons $[75,76,79]$. Of note, noncycling tumor cells $\left(G_{0}-G_{1}\right)$ appear to be a more sensitive target for the antiproliferative activity of human interferon $[80,81]$.

Crude murine alpha interferon preparations have been shown to inhibit the growth of transplantable tumors of diverse origins (melanoma, friend leukemia, osteogenic sarcoma, Lewis lung, Ehrlich ascites) [82-85]. In support of a direct antiproliferative effect are studies of transplanted human tumors in immunodeficient nude mice in which immunomodulatory effects of administered human alpha interferon are minimal $[86,87]$. Dose-dependent growth inhibition is observed in these models and persists only for the duration of treatment $[86,87]$. Evidence for direct antiproliferative effect in human trials is suggested in cutaneous $T$ cell lymphoma. Four of 10 patients who had had a relapse while receiving a 10 percent maintenance dosage demonstrated responses after reescalation to 100 percent dosage [37].

\section{IMMUNOMODULATORY ACTIVITY}

Immunomodulatory activities of interferon are also of considerable interest and may possibly play a role in the anticancer effect. The first evidence of this indirect effect of interferon was demonstrated when mice inoculated with L1210 cells derived from an interferon-resistant clone were still protected by daily interferon treatment [88]. Because the resistant cells did not revert to interferon-sensitive cells in vivo, these experiments were interpreted as suggesting that an antitumor effect was mediated by the host, rather than by a direct effect on cell multiplication. Subsequently it has been shown that alpha interferon can enhance as well as suppress cell-mediated 
and humoral immune responses that are believed to play an active role in tumor surveillance.

Natural Killer Activity and Antibody-Dependent Cellular Cytotoxicity. Natural killer cells are a heterogeneous population of lymphocytes that are cytotoxic against several cell types and tumors in vitro [89]. Morphologically, human natural killer cells are identified as large granular lymphocytes. Direct evidence exists that natural killer cells inhibit in vivo tumor growth in animals; inhibition in humans has thus far been indirect and less consistent [90]. In in vitro systems, human natural killer cell cytolytic activation is consistently enhanced in the presence of both crude and pure alpha interferon [91-93]. There is conflicting evidence regarding the natural killer cell-activating effects of interferon in human therapy. Using both crude and pure alpha interferon, many clinical studies have documented interferon-induced increases in natural killer cell activity [94,95], whereas other investigators reported a lack of effect on natural killer activity or occasional depression of natural killer cytolytic activity by interferon $[96,97]$. To define the parameters governing this effect, purified lymphoblastoid interferon was given in one study in six dosages, ranging from $10^{5}$ to $3 \times 10^{7}$ units intramuscularly per week to cancer patients [98]. A negative correlation between the amount of interferon injected and the natural killer cell activity was found; cytolysis peaked at 24 hours after injection of $3 \times 10^{6}$ units (a three-fold increase).

The exact mechanism by which interferon stimulates natural killer cell activity and by which natural killer cells lyse their targets is not fully understood. Some evidence suggests that interferon is able to induce differentiation of precursor cells into mature natural killer cells and to directly activate preexisting mature natural killer cells $[99,100]$. More recently, release of a natural killer cytotoxic factor has been shown in supernatants of natural killer cells exposed to appropriate tumor target cells, and this cytotoxic factor is believed to be involved in natural killer-mediated cytolysis [101]. Addition of alpha interteron to human lymphocytes results in augmentation of natural killer cytotoxic factor production [101]. Further in vitro studies suggest that alpha interferon may be required for both the production of natural killer cytotoxic factor and the modulation of its lytic activity [102].

The lysis of specific antibody-coated target cells, known generally as antibody-dependent cellular cytotoxicity, has also been shown to be mediated by large granular lymphocytes [103]. Several studies have indicated that both crude and purified alpha interferon preparations are able to augment antibody-dependent cellular cytotoxicity responses mediated by human lymphocytes in vitro $[91,104]$. This increase also occurred against target cells resistant to natural killer activity [105]. More recently, it has been shown that pure alpha interferon enhances the antibody-dependent cellular cytotoxicity of human polymorphonuclear leukocytes against several hematologic cell lines in vitro [106]. Interestingly, the effect was most pronounced when the lgG antibodies in the antibody-dependent cellular cytotoxicity reaction were present in suboptimal amounts; this suggests that interferon may play a role in initial in vivo immune response when IgG levels are still low [106]. Interferon may augment this activity by increasing the expression of FcG receptors on the lymphocyte cell surface, enhancing the binding of immunoglobulin-coated target cells [107]. Like the natural killer cell response in human trials, antibody-dependent cellular cytotoxicity response in patients receiving pure alpha interferon is variable [108].

Monocyte Function. Monocytes and macrophages are bone marrow-derived cells that have the capacity of phagocytosis and pinocytosis and more recently have been shown to be tumoricidal in vitro and in animal models [109]. Like natural killer cell activation, alpha interferon in vitro enhances tumoricidal monocyte function $[92,110]$. Unlike natural killer cell activation, human clinical trials with both crude and recombinant alpha interferon have shown consistent activation of monocyte tumoricidal function $[96,97]$. The exact mechanism by which interferon activates monocytes in man remains unknown. Recent studies using recombinant interferon suggest that interferon acts as an inducer of macrophage Fc receptor-mediated phagocytosis [111]. Recombinant gamma interferon was significantly more potent than either alpha or beta interferon. Some studies suggest that gamma interferon is the major natural human lymphokine (known as the macrophage-activating factor) capable of inducing monocyte-macrophage tumoricidal activity [112]. The role of activated macrophages in tumor surveillance or tumoricidal activity in humans is currently under investigation.

B Lymphocytes. In vitro and in vivo studies of the effect of alpha interferon on immunoglobulin synthesis by B cells demonstrate that dosage and time of exposure are important. Pretreatment of human peripheral blood B lymphocytes with both crude and pure alpha interferon before addition of mitogen enhances immunoglobulin production, but interferon treatment after exposure to mitogen suppresses production $[113,114]$. Lower doses of alpha interferon enhance maturation of $B$ cells, whereas suppression occurs at higher doses $[115,116]$. The enhanced immunoglobulin production occurs even when peripheral blood lymphocytes are separated into $T$ and $B$ cell subpopulations before interferon administration, suggesting a direct effect on $B$ cells $[113,114]$. The first in vivo evidence suggesting an effect of interferon on antibody formation came from studies with mice [117]. Preliminary studies in human trials have demonstrated minimal increases of immunoglobulin secretion at $30 \times 10^{6}$ units, but not at other dosages [108]. Similar to the interferon effect on macrophages, gamma interferon has 
been shown to be a more potent regulator of antibody response than alpha or beta interferon on an antiviral unit basis [118].

T Cells. T lymphocytes are the effector cells of cellmediated immunity, and they perform a variety of functions including cellular cytotoxicity, helper and suppressor activity, and lymphokine production. The effect of interferon on $T$ cells is complex: some phases of the $T$ cell responses may be enhanced and others depressed. In vitro, alpha interferon enhances the cytotoxicity of the mixed lymphocyte cultures; however, proliferation is inhibited [119]. Both inhibition and activation of T suppressor cells from mixed lymphocyte cultures have been observed $[120,121]$. In clinical trials, both crude and recombinant interferon has been shown to depress lymphoproliferative response to mitogens and mixed lymphocyte culture $[96,97]$. The importance of interferon's effects on $T$ cells as it relates to antitumor effect is not known.

Modulation of Cell Surface Antigens. Interferon induces a variety of changes in the cell surface including increases in the expression of Fc receptors on lymphocytes and macrophages that enhance tumoricidal activity $[107,111]$. Consistent, increased expression of HLA antigens $A, B$, and $C$ and the $H L A$ subunit $B_{2}$-microglobulin is observed with alpha, beta, and gamma interferon, both in vivo and in vitro $[122,123]$. Only gamma interferon has consistently increased expression of HLA-DR [124]; moreover, human gamma interferon, unlike alpha or beta, is able to increase expression of HLA-A, $B$, and $C$ proteins on the cell surface at concentrations considerably lower than those necessary to induce an antiviral effect [125]. Because the HLA-DR system in humans appears to play a major role in the presentation of antigen for immune response [126], gamma interferon may have a more important role in treatment directed at cell surface proteins than either alpha or beta interferon.

Oncogene Expression. Neoplastic transformation of normal cells to malignant cells is now believed to be regulated by expression of cellular oncogenes. Rat fibroblast cells exposed to the Rous sarcoma virus undergo malignant transformation resulting from the expression of the viral src oncogene. The product of this gene has been shown to be a tyrosine phosphokinase $\left(\mathrm{pp}^{\mathrm{src}}\right)$ [127] that is capable of inducing this transformation. Treatment of Rous sarcoma virus-transformed rat cells with rat crude alpha interferon resulted in a 50 percent decrease in

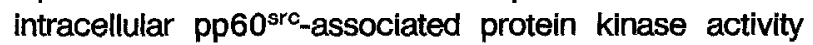
and a more normal growth pattern [128]. Moreover tritiated leucine pulse labeling experiments showed that interferon worked by selectively reducing the synthesis of the src gene product [128].

Recombinant human alpha interferon has been shown to decrease accumulation of the cellular myc oncogene messenger RNA in the Daudi cell line (Burkitt's lymphoma) [129]. The effect is dose-dependent and occurs before any inhibition of cell growth can be detected. Interestingly, no effect was seen on c-myc transcription rates, but rather an accelerated degradation of c-myc messenger RNA was noted ( 67 to 80 percent decrease in c-myc messenger RNA half-life) [129].

Effect of crude alpha interferon on oncogene expression in peripheral blood cells from two patients with chronic myelogenous leukemia has also been studied [130]. Although the expression of several oncogenes (sis, ras-Harvey, ras-Kirsten, and myc) remained unchanged during interferon therapy, a significant decrease in $a b l$ oncogene expresslon was detected within a few days after treatment was initiated in both patients. The results of these three studies suggest another mechanism by which interferon may inhibit tumor growth.

\section{MECHANISMS OF INTERFERON ACTIVITY IN SPECIFIC DISEASES}

Hairy cell leukemia is the model disease for studying the effects of alpha interferon. Patients with hairy cell leukemia have a severe deficlency in natural kllier cell activity. Recovery of natural killer activity has been reported $[24,131]$ in most patients with hairy cell leukemia after alpha interferon therapy. The recovery of natural killer cells paralleled hematologic recovery. It remains unclear whether the natural killer cells played a direct role in hematologic recovery or were simply a byproduct of interferon-induced hematologic recovery. However, it was of interest that the low natural killer activity in the untreated cells was not really attributable to a relative deficiency or dilution of the effector cells because the percent of Leu11-positive cells, which identify the natural killer cells, was within the normal range. This suggests that alpha interferon activated these cells into functional effector cells [24]. in addition to natural killer cell recovery, improvement in the total numbers of $T$ lymphocytes including both helper and suppressor populations and monocytes paralleled the improvement in the other hematologic parameters after alpha interferon therapy.

Hairy cell leukemia and low-grade lymphomas are both indolent diseases of B cell origin. Alpha interferon has a high degree of activity in both diseases [18-27,29-35]. The lack of responsiveness of another indolent $B$ cell malignancy, chronic lymphocytic leukemia, has as yet been unexplained $[35,40-44]$. A comparison of binding of iodinated recombinant alpha interferon to normal peripheral blood mononuclear cells, hairy cell leukemia cells, and chronic lymphocytic leukemia cells demonstrated that hairy cells bound approximately twice as much iodinated interferon as chronic lymphocytic leukemia and normal cells; however, the hairy cells had twice the surface area, which may explain the greater number of receptors [132].

Alpha interferon has been reported to induce cell surface and intracellular proteins in patients with hairy cell leukemia [133]. Autoradiographic analysis of one-dimen- 
sional polyacrylamide gels showed induction of at least six proteins in nine patients treated with recombinant alpha interferon. Overall protein synthesis was not significantly altered. Some of these proteins were in the cell membrane, leading the investigators to suggest that interferon induces a protein signal in the hairy cell enabling their destruction [133].

Most recently Baldini and coworkers [134] isolated hairy cells from the spleens of previously untreated patients and cultured them in the presence of recombinant human alpha interferon. Monoclonal antibody surface marker studies revealed a significant enhancement of class II HLA antigen (HLA-DR). Because HLA antigens have been shown to be involved in cell-mediated cytotoxicity [126], they speculated that selective enhancement of class II HLA antigen may be another in vivo therapeutic mechanism of alpha interferon.

\section{CONCLUSIONS}

The importance of interferon as a direct antitumor agent or a biologic response-modifier remains an unanswered question in the treatment of malignant diseases. Although it is clear that interferon will not be effective in most cancers, we have reviewed interferon's effectiveness in managing some of the hematologic malignancies. Even in these diseases, the optimal dose of interferon is uncertain. High doses may have greater direct antiproliferative activity, yet they may also suppress the immune system. Low doses may be more effective in enhancing the immune system. Interferon's role as a first-line treatment or in combination with standard cytotoxic drugs or other biologic response-modifiers is an area of ongoing research. Regardless of the eventual role of alpha interferon in the treatment of cancer, it is an important first member of a family of biologic response-modifiers used in treating human malignancies.

\section{ACKNOWLEDGMENT}

We would like to thank Dr. Michael J. Hawkins for his review of this manuscript and Anne Meconi for her excellent secretarial assistance in preparation of this manuscript.

\section{REFERENCES}

1. Isaacs A, Lindenman J: Virus interference: I. The interferon. Proc R Soc Lond Biol 1957; 147: 258-267.

2. Stewart WE II, Blalock JE, Burke DC, et al: Interferon nomenclature (letter). J Immunol 1980; 125: 2353.

3. Fleischmann WR, Klimpel GR, Tyring SK, Voss WR, Baron $\mathrm{S}$ : Interferon and cancer: current use and novel approaches. In: Sunkara PS, ed. Novel approaches to cancer chemotherapy. Orlando, Florida: Academic Press, $1984 ; 1-22$.

4. Sehgal PB: The interferon gene. Biochem Biophys Acta 1982; 695: 17-33.

5. Borden EC: Progress toward therapeutic application of interferons, 1979-1983. Cancer 1984; 54: 2770-2776.

6. Hawkins MJ, Borden EC, Merritt JA, et al: Comparison of the biologic effects of two recombinant human interferons alpha (rA and $\mathrm{rD}$ ) in humans. J Clin Oncol 1984; 2: 221-226.

7. Cantell K, Hirvonen S: Preparation of human leukocyte interferon for clinical use. Texas Rep Biol Med 1977; 35: 138-144.

8. Pestka S: The purification and manufacture of human interferons. Sci Am 1983; 249: 37-43.

9. Lin LS, Stewart WE Il: Purification of human leukocyte interferon by two-dimensional polyacrylamide gel electrophoresis. Methods Enzymol 1981; 78: 481-487.

10. Berg K, Heron I: Antibody affinity chromatography of human leukocyte interferon. Methods Enzymol 1981; 78 : 487-499.

11. Epstein LB: Interferon-gamma: success, structure and speculation. Nature 1982; 295: 453-454.

12. Yip YK, Pang RHL, Urban C, Vilcek J: Partial purification and characterization of human gamma (immune) interferon. Proc Natl Acad Sci USA 1981; 78: 1601-1605.

13. Kirkwood JM, Ernstoff MS: Interferons in the treatment of human cancer. J Clin Oncol 1984; 2: 336-352.

14. Bonnem EM, Spiegel RJ: Interferon-alpha: current status and future promise. J Biol Response Mod 1984; 3: 580-598.

15. Auerbuch SD, Austin HA, Sherwin SA, et al: Acute interstitial nephritis with nephrotic syndrome following recombinant leukocyte $A$ interferon therapy for mycosis fungoides. N Engl J Med 1984; 301: 32-35.

16. Sherwin SA, Knost JA, Fein S, et al: A multiple-dose phase I trial of recombinant leukocyte $A$ interferon in cancer patients. JAMA 1982; 248: 2461-2466.

17. Golomb HM: Hairy cell leukemia: an unusual lymphoproliferative disease. A study of 24 patients. Cancer 1978; 42 : 946-956.

18. Quesada JR, Reuben J, Manning JT, Hirsch EM, Gutterman $\mathrm{JU}:$ Alpha interferon for induction of remission in hairy cell leukemia. N Engl J Med 1984; 310: 15-18.

19. Quesada JR, Hersh EM, Gutterman JU: Treatment of hairy cell leukemia with alpha interferon (abstr). Proc Am Soc Clin Oncol 1984; 3: 207.

20. Quesada JR, Hersh EM, Manning JT, et al: Treatment of hairy cell leukemia with recombinant alpha interferon. Blood 1986; 68: 493-497.

21. Ratain MJ, Golomb HM, Vardiman JW, Vokes EE, Jacobs $\mathrm{RH}$, Daly K: Treatment of hairy cell leukemia with recombinant alpha $\mathrm{A}_{2}$ interferon. Blood 1985; 65: 644-648.

22. Jacobs $A D$, Champlin RE, Golde DW: Recombinant alpha2-interferon for hairy cell leukemia. Blood 1985; 65: 1017-1020.

23. Thompson JA, Fefer A, Bonnem E: The treatment of hairy cell leukemia with recombinant alpha-2-interferon (abstr). Blood 1984; 64 (suppl 1): 613.

24. Foon KA, Maluish AE, Abrams PG, et al: Recombinant leukocyte $A$ interferon therapy for advanced hairy cell leukemia: therapeutic and immunologic results. Am J Med 1986; 80: 351--356.

25. Worman CP, Catovsky D, Bevan PC, et al: Interferon is effective in hairy-cell leukemia. $\mathrm{Br} J$ Haematol 1985; 60: 
759-763.

26. Habermann T, Hoagland H, Chang M, Phylldy R: A phase II trial of alpha recombinant interferon in hairy cell leukemia in patients with advanced disease (abstr). Blood 1985; 66 (suppl 1): 2009.

27. Castaigne $S$, Sigaux $F$, Cantell $K$, et al: Interferon alpha in the treatment of hairy cell leukemia. Cancer 1986; 57 : $1681-1684$

28. Non-Hodgkin's Lymphoma Pathologic Classification Project: National Cancer Institute-sponsored study of classifications of non-Hodgkin's lymphomas. Summary and description of a working formulation for clinical use. Cancer 1982; 49: 2112-2135.

29. Merigan TC, Sikora K, Bredden JH, Levy R, Rosenberg SA: Preliminary observations on the effect of human leukocyte interferon in non-Hodgkin's lymphoma. NEngl J Med 1978; 299: 1449-1453.

30. Loule AC, Gallagher JG, Sikora K, Levy R, Rosenbery SA Merigan TC: Follow-up observations on the effect of human leukocyte interferon in non-Hodgkin's lymphoma. Blood 1981; 58: 712-718.

31. Foon KA, Sherwin SA, Abrams PG: Treatment of advanced non-Hodgkin's lymphoma with recombinant leukocyte $A$ interferon. N Engl J Med 1984; 311: 1148-1152.

32. O'Connell MJ, Colgan JP, Oken MM, Ritts RE, Kay NE, Itrì LM: Clinical trial of recombinant leukocyte $A$ interferon as initial therapy for favorable histology non-Hodgkin's lymphomas and chronic lymphocytic leukemia. J Clin Oncol 1986: 4: 128-136.

33. Horning SJ, Merigan TC, Krown SE, et al: Human interferon alpha in malignant lymphoma and Hodgkin's disease. Cancer 1985; 56: 1305-1310.

34. Leavitt RD, Kaplan R, Ozer H: Low dose alpha-2 interferon treatiment for low grade non-Hodgkin's lymphoma (abstr) Blood 1984; 64 (suppl I): 182a.

35. Gutterman JU, Blumenschein GR, Alexanian R: Leukocyte interferon-induced tumor regression in human metastatic breast cancer, multiple myeloma, and malignant lymphoma. Ann Intern Med 1980; 93: 399-406.

36. Leavitt RD, Ratanatharathorn V, Ozer H, Rudnick S, FerraresI R: A phase II study of recombinant alpha 2 Interferon in patients with malignant lymphoma with unfavorable histology (abstr). Proc Am Soc Clin Oncol 1983; 2: 54.

37. Bunn PA, Foon KA, Inde DC: Recombinant leukocyte A interferon: an active agent in advanced cutaneous T-cell lymphomas. Ann Intern Med 1984; 101: 484-487.

38. Bunn PA, Idhe DC, Foon KA: The role of recombinant interferon alpha-2a in the therapy of cutaneous $\mathrm{T}$-cell lymphomas. Cancer 1986; 57: 1689-1695.

39. Gale RP, Foon KA: Chronic lymphocytic leukemia, recent advances in biology and treatment. Ann Intern Med 1985. 103: 101-120.

40. Misset JL, Mythe G, Gastiaburu J, et al: Treatment of leukemias and lymphomas by interferons: phase II trial of chronic lymphoid leukemia by human interferon alpha. Biomed Pharmacother 1982; 36: 112-116.

41. Huang A, Laszlo J, Brenckman W: Lymphoblastoid interferon (Wellferon) trial in chronic lymphocytic loukemia (abstr). Proc Am Assoc Cancer Res 1982; 23: 113

42. Foon KA, Bottino G, Abrams PG: Phase II trial of recombinant leukocyte $A$ interferon in patients with advanced chronic lymphocytic leukemia. Am J Med 1985; 78: 216-220.

43. Ozer $H$, Leavit $R$, Ratanatharathorn $V$ : Experience in the use of DNA alpha-2 interferon in the treatment of malignant lymphoma (abstr). Am Soc Hematol 1983; 62: 211a.

44. Schulof RS, Lloyd MI, Stallings JJ, et al: Recombinant leukocyte $A$ interferon in B-cell chronic lymphocytic leukemia: in vivo effects on autologous antitumor immunity. J Biol Response Mod 1985; 4: 310-323.
45. Bergsagel D: Plasma cell myeloma. In: Williams W, Beutler E, Ersleu A, Lichtman M, eds. Hematology. New York: McGraw-Hill, 1983; 1078-1099.

46. Mellstedt $H$, Bjorkholm $M$, Johansson $B$, Ahre A, Holm G, Strander $\mathrm{H}$ : Interferon therapy in myelomatosis. Lancet 1979; I: 245-248.

47. Bjorkholm M: Daily low dose interferon versus intermittent high dose melphalan/prednisone treatment in multiple myeloma (abstr). Proc Am Soc Clin Oncol 1983; 2: 242.

48. Osserman EF, Sherman WH, Alexanian R, Gutterman J: Preliminary results of the American Cancer Society (ACS) sponsored trial of human leukocyte interferon (IF) in multiple myeloma (MM) (abstr). Am Assoc Cancer Res 1980; $21: 161$.

49. Ohno R, Kimura K: Treatment of multiple myeloma with recombinant interferon alpha-2a. Cancer 1986; 57: 1685-1688.

50. Costanzi J, Cooper MR, Scarffe JH, et al: Phase II study of recombinant alpha ${ }_{2}$-interferon in resistant multiple myeloma. J Clin Oncol 1985; 3: 654-659.

51. Quesada JR, Alexanian R, Gutterman JU: Induction of remission and restoration of serum immunoglobulins in multiple myeloma with recombinant DNA-derived interferon (rIFNaA) (abstr). Blood 1984; 64 (suppl I): 183a.

52. Wagstaff $\mathrm{J}$, Loynds $\mathrm{P}$, Scarffe $\mathrm{JH}$ : Phase II study of rDNA human alpha-2 interferon in multiple myeloma. Cancer Treat Rep 1985; 69: 495-498.

53. Case DC, Sonneborn HL. Paul SO, et al: Phase II study of rDNA alpha-2 interferon (Intron A) in patients with multiple myeloma utilizing an escalating induction phase (abstr). Blood 1985; 66 (suppl 1): 213a.

54. Clark RH, Dimitrov NV, Axeison JA, Charamella LJ: Leukocyte interferon as a possible biological response modifier in lymphoproliferative disorders resistant to standard therapy. J Biol Response Mod 1984; 3: 613-619.

55. Champlin RE, Goide DW: Chronic myelogenous leukemia: recent advances. Blood 1985; 65: 1034-1047.

56. Talpaz M, Kantarjian H, McCredie MJ, et al: Clinical study of human alpha interferon in chronic myelogenous leukemia (abstr). Blood 1985; 66 (suppl 1): $209 a$.

57. Talpaz M, Mavligit G, Keating M, Walters RS, Gutterman JU: Human leukocyte interferon to control thrombocytosis in chronic myelogenous leukemia. Ann Intern Med 1983; 99: 789-792.

58. Talpaz M, Kantarjian HM, McCredie K, Trujillo JM, Keating $\mathrm{MJ}$, Gutterman JU: Hematologic remission and cytogenetic improvement induced by recombinant human interferon alpha $\mathrm{A}$ in chronic myelogenous leukemia. $\mathrm{NEngl} J$ Med 1986; 314: 1065-1069.

59. Velu T, Delwiche F, Flument J, Monsieur R, Stryckmans P, Wybran J: Therapy of essential thrombocythemia with human alpha-2 recombinant interferon (abstr). Blood 1984; 64 (suppl 1): 176a.

60. Hill NO, Pardue A, Khan A, Aleman C, Hilario R, Hill JM: Clinical trials of human leukocyte interferon in malignancy. Texas Rep Biol Med 1982; 41: 634-638.

61. Hill NO, Pardue A, Khan A, Aleman C, Dorn G, Hill JM: Phase I human leukocyte interferon trials in cancer and leukemia. J Clin Hematol Oncol 1981; 11: 23-35.

62. Rohatiner AZS, Balkwill FR, Griffin DB, Malpas JS, Lister TA: A phase I study of human lymphoblastoid interferon administered by continuous intravenous infusion. Cancer Chemother Pharmacol 1982; 9: 97-102.

63. Rohatiner AZS, Balkwill FR, Malpas JS, Lister TA: Experience with human lymphoblastoid interferon in acute myelogenous leukemia. Cancer Chemother Pharmacol 1983; 11: 56-58.

64. Leavitt RD, Duffey P, Wiernik PH: A phase I/II study of recombinant leukocyte-A interferon in previously treated acute leukemia (abstr). Am Soc Hematol 1983; 62: 205a. 
65. Williams BRG: Biochemical actions of interferon. In: Sikora $\mathrm{K}$, ed. Interferon and cancer. New York: Plenum Press, 1983; 33-52.

66. Feinstein S, Traub A, LaZar A, Mizrahi A, Teitz Y: Studies on cell binding and internalization of human lymphoblastoid interferon. J Ifn Res 1985; 5: 65-67.

67. Ball LA: Induction of $2^{\prime}-5^{\prime}$-oligoadenylate synthetase activity and a new protein by chick interferon. Virology 1979; 94: 282-296.

68. Ball LA: $2^{\prime}-5^{\prime}$-oligoadenylate synthetase. In: Boyer PD, ed. The enzymes, vol XV. New York: Academic Press, 1982; 281-313.

69. Merlin G, Chebath J, Benech P, Metz R, Revel M: Molecular cloning and sequence of partial CDNA for interferoninduced $\left(2^{\prime}-5^{\prime}\right)$ oligo(A) synthetase mRNA from human cells. Proc Natl Acad Sci USA 1983; 80: 4904-4908.

70. Revel M, Kimchi $A$, Shulman $L$, et al: Role of interferon induced enzymes in the antivlral and antimitogenlc effects of interferon. Ann NY Acad Sci 1980; 350: 349-472.

71. Bischoff JR, Samuel CE: Mechanism of interferon action. J Biol Chem 1985; 260: 8237-8239.

72. Schatiner A, Merlin G, Wallach D, et al: Monitoring of interferon therapy by assay of $2^{\prime} 5^{\prime}$-oligoisoadenylate synthetase in human peripheral white blood cells. $\mathrm{J}$ Ifn Res 1981; 1: 587-594.

73. Merritt JA, Borden EC, Ball LA: Measurement of $2^{\prime}, 5^{\prime}-$ oligoadenylate synthetase in patients receiving interferon-alpha. J Ifn Res 1985; 5: 191-198.

74. Balkwill FR, Oliver RTD: Growth inhibitory effects of interferon on normal and malignant human haemopoietic cells. Int J Cancer 1977; 20: 500-505.

75. Borden EC, Hogan TF, Voelkel JG: Comparative antiproliferative activity in vitro of natural interferons alpha and beta for diploid and transformed human cells. Cancer Res 1982; 42: 4948-4953.

76. Chadha KC, Srivastava BI: Comparison of the antiproliferative effects of human fibroblast and leukocyte interferons on various leukemic cell lines. $\mathrm{J}$ Clin Hematol Oncol 1981; 11: 55-60.

77. Salmon SE, Durie BGM, Young L, Liu RM, Trown P, Stebbing $\mathrm{N}$ : Effects of cloned human leukocyte interferons in the human tumor stem cell assay. J Clin Oncol 1983; 1: 217-225.

78. Denz H, Lechleitner M, Marth $\mathrm{CH}$, Daxenbichler $\mathrm{G}$, Gastl $\mathrm{G}$, Braunsteiner $\mathrm{H}$ : Effect of human recombinant alpha-2and gamma-interferon on the growth of human cell lines from solid tumors and hematologic malignancies. J Ifn Res 1985; 5: 147-157.

79. Blalock J, Georgiades JE, Langford MP, Johnson HM: Purified human immune interferon has more potent anticellular activity than fibroblast or leukocyte interferon. Cell Immunol 1980; 49: 390-394.

80. Horoszewicz JS, Leong SS, Carter WS: Noncycling tumor cells are sensitive targets for the antiproliferative activity of human interferon. Science 1979; 206: 1091-1093.

81. Creasey AA, Batholomew JC, Merigan TC: Role of G0-G1 arrest in the inhibition of tumor cell growth by interferon. Proc Natl Acad Sci USA 1980; 77: 1471-1475.

82. Bart RS, Porzio NR, Kopf AW, Vilcek JT, Cheng EH, Farcet $Y$ : Inhibition of growth of B-16 murine malignant melanoma by exogenous interferon. Cancer Res 1980; 40: 614619.

83. Rossi GB, Marchegiani M, Matarese GP, Gresser I: Brief communication: inhibitory effect of interferon on multiplication of friend leukemia cells in vivo. JNCI 1975; 54: 993-996.

84. Crane JL, Glasgow LA, Kern ER, Youngner JS: Inhibition of murine osteogenic sarcomas by treatment with type I or type II interferon. JNCl 1978; 61: 871-874.
85. Gresser I, Tovey M: Antitumor effects of interferon. Biochem Biophys Acta 1978; 516: 231-247.

86. Yoshitake $Y$, Kishida T, Esaki K, Kawamata J: Antitumor effects of interferon on transplanted tumors in congenitally athymic nude mice. Giken J 1976; 19: 125-127.

87. Balkwill FR, Moodie EM, Freedman V, Fantes KH: Human interferon inhibits the growth of established human breast tumors in the nude mouse. Int J Cancer 1982; 30: 231-235.

88. Gresser I: Antitumor effects of interferon. Adv Cancer Res 1972; 16: 97-140.

89. Barlozzari T, Leonhardt J, Wiltrout RH, Herberman RB, Reynolds CW: Direct evidence for the role of LGL in the inhibition of experimental tumor metastases. J Immunol 1985; 134: 2783-2789.

90. Herberman RB, Ortaldo JR: Natural killer cells: their role in defenses against diseases. Science 1981; 214: 24-30.

91. Herberman RB, Ortaldo JR, Bonnard G: Augmentation by interferon of human natural and antibody-dependent cell mediated cytotoxicity. Nature 1979; 277: 221-223.

92. Herberman RB, Ortaldo JR, Rubinstein M, Pestka S: Augmentation of natural and antibody-dependent cell mediated cytotoxicity by pure human leukocyte interferon. $J$ Clin Immunol 1981; 1: 149-153.

93. Herberman RB, Ortaldo JR, Mantovani A, Hobbs DS, Kung $\mathrm{H}-\mathrm{F}$, Pesta S: Effect of human recombinant interferon on cytotoxic activity of natural killer cells and monocytes. Cell Immunol 1982; 67: 160-167.

94. Huddleston JR, Merigan TC, Oldstone MBA: Induction and kinetics of natural killer cells in humans following interferon therapy. Nature $1979 ; 282: 417-419$.

95. Borden EC, Holland JF, Dao T, et al: Leukocyte-derived interferon (alpha) in human breast carcinoma. American Cancer Society phase II trial. Ann Intern Med 1982; 97 : 1-6.

96. Maluish AE, Ortaldo JR, Sherwin SA, Oldham RK, Herberman RB: Function in patients receiving natural leukocyte interferon. J Biol Response Mod 1983; 2: 418-427.

97. Maluish AE, Leavitt R, Sherwin SA, Oldham RK, Herberman RB: Effects of recombinant interferon-alpha on immune function in cancer patients. J Biol Response Mod 1983; 2: 470-481.

98. Edwards BS, Merritt JA, Fuhlbrigge RC, Bordon EC: Low doses of interferon alpha result in more effective clinical natural killer cell activation. J Clin Invest 1985; 75 : 1908-1913.

99. Targan S, Dorey F: Interferon activation of "pre-spontaneous killer" cells (pre-sk) and alteration in kinetics of lysis of both "pre-sk" and active sk cells. J Immunol 1980; 124: 2157-2161.

100. Timonen T, Ortaldo JR, Herberman RB: Analysis by a single cell cytotoxicity assay of natural killer (NK) cell frequencies among human large granular lymphocytes and of the effects of interferon on their activity. J Immunol 1982; 128: 2514-2521.

101. Wright SC, Bonauida B: Role of natural killer cytotoxic factors (NKCF) in the mechanism of NK cell mediated cytotoxicity. In: Herberman RB, ed. NK cells and other natural effector cells. New York: Academic Press, 1982; 961-968.

102. Steinhauer EH, Doyle AT, Kadlsh AS: Human natural killer cytotoxic factor (NKCF): role of IFN-alpha. J Immunol 1985; 135: 294-299.

103. Timonen $T$, Ortaldo JR, Herberman RB: Characteristics of large granular lymphocytes and relationship to natural killer and killer cells. J Exp Med 1981; 153: 569-582.

104. Masucci MG, Sziget $R$, Klein $E$, et al: Effect of interferonalpha-1 from $E$. coll on some cell functions. Science 1980; 209: 1431-1435

105. Ortaldo JR, Pestka S, Slease RB, Rubinstein M, Herberman 
RB: Augmentation of human K-cell activity with interferon. Scand J Immunol 1980; 12: 365-369.

106. Hokland $P$, Berg $K$ : Interferon enhances the antibody-dependent cellular cytotoxicity of human polymorphonuclear leukocytes. J Immunol 1981; 127: 1585-1588.

107. Djeu JY: Regulation of cell functions by interferon. In: Zoon KC, Noguchi PO, Liu T-Y, eds. Interferon: research, clinical application, and regulatory consideration. New York: Elsevier, 1984; 125-131.

108. Ozer H, Gavigan M, O'Malley J, et al: Immunomodulation by recombinant interferon-alpha-2 in a phase 1 trial in patients with lymphoproliferative malignancies. J Biol Response Mod 1983; 2: 499-515.

109. Rosenstreich DL: The macrophage. In: Oppenheim JJ, Rosenstrelch DL, Potter M, eds. Cell functions In Immunity and inflammation. New York: Elsevier North Holland, 1981; 127-159.

110. Sone S, Utsugi T, Shirahama T, Ishii K, Mutsuura S, Mitsumasa $O$ : Induction by interferon-alpha of tumoridical activity of adherent mononuclear cells from human blood: monocytes as responder and effector cells. J Biol Response Mod 1985; 4: 134-140.

111. Fertsch $D$, Vogel SN: Recombinant interferons increase macrophage Fc receptor capacity. J Immunol 1984; 132: 2436-2439.

112. Sadlik JR, Hoyer M, Leyko MA, et al: Lymphocyte supernatant-induced human monocyte tumoricidal activity: dependence on the presence of gamma-interferon. Cancer Res 1985; 45: 1940-1945.

113. Harfast $B$, Huddleston JR, Casali $P$, Merigan TC, Oldstone MBA: Interferon acts directly on human $B$ lymphocytes to modulate immunoglobulin synthesis. J Immunol 1981; 127: 2146-2150.

114. Rodriguez MA, Prinz WA, Sibbitt WL, Bankhurst AD, Williams RC: Alpha-interferon increases immunoglobulin production in cultured human mononuclear leukocytes. J Immunol 1983; 130: 1215-1219.

115. Choi YS, Lim KH, Sanders FK: Effect of interferon-alpha on pokeweed mitogen-induced differentiation of human peripheral blood B lymphocytes. Cell Immunol 1981; 64: 20-28.

116. Fleisher TA, Attallah AM, Tosato $O$, Blaese RM, Greene WC: Inhibition of human polyclonal immunoglobulin synthesis. J Immunol 1982; 129: 1099-1103.

117. Braun W, Levy HB: Interferon preparations as modifiers of immune responses. Proc Soc Exp Biol Med 1972; 141: $769-773$.

118. Sonnefeld G: Effects of interferon on antibody formation. In: Vilcek $\mathrm{l}$, DeMaeyer E, eds. Interferon, vol 2: interferons and the immune system. Amsterdam: Elsevier, 1984; 85-99.

119. Heron I, Berg K, Cantell K: Regulatory effect of interferon on T-cells in vitro. J Immunol 1976; 117: 1370-1373.

120. Fradelizi $D$, Gresser I: Interferon inhibits the generation of allospecific suppressor T lymphocytes. J Exp Med '1982; 155: $1610-1622$.

121. Schnaper HW, Aune T, Pierce C: Suppressor T cell activation by human leukocyte interferon. J Immunol 1983; 131: 2301-2306.

122. Gresser I: The effect of interferon on the expression of surface antigens. In: Vilcek J, DeMaeyer E, eds. Interferons and the immune system. Amsterdam: Elsevier, 1984; 113-132.

123. Heron I, Hokland $M$, Berg K: Enhanced expression of $B_{2-}$ microglobulin and HLA antigens on human lymphoid cells by interferon. Proc Natl Acad Sci USA 1978; 75: 62156219.

124. Kelley VE, Fiers W, Strom TB: Cloned human interferongamma, but not interferon-beta or alpha, induces expression of HLA-DR determinants by fetal monocytes and myeloid leukemic cell lines. J Immunol 1984; 132: 240245.

125. Wallach D: The HLA proteins and a related protein of 28 $\mathrm{Kd}_{\mathrm{A}}$ are preferentially induced by interferon-gamma in human WISH cells. Eur J Immunol 1983; 13: 794-798.

126. Meur SC, Schlossman SF, Reinherz EL: Clonal analysis of human cytotoxic T-lymphocytes T-4+ and T-8+ effector T-cells recognize products of different major histocompatability complex regions. Proc Natl Acad Sci USA 1982; 79: 4395-4399.

127. Erikson RL, Purchio AF, Erikson E, Collet MS, Brugge JS: Molecular events in cells transformed by Rous sarcoma virus. J Cell Biol 1980; 87: 319-325.

128. Lin SL, Garber EA, Wang E, et al: Reduced synthesis of pp60 and expression of the transformation-related phenotype in interferon-treated Rous sarcoma virus-transformed rat cells. Mol Cell Biol 1983; 3: 1656-1664.

129. Dani $\mathrm{CH}$, Mechti N, Piechaczyk M, Lebleu B, Jeanteur PH, Blanchard JM: Increased rate of degradation of c-myc mRNA in interferon-treated Daudi cells. Proc Natl Acad Sci USA 1985; 82: 4891-4899.

130. Strayer DR, Gillespie DH, Bressuer J, Brodsky I: Oncogene expression decreased in two patients treated with interferons (abstr). Blood 1984; 64 (suppl I): 175a.

131. Semenzato G, Pizzolo G, Agostini G, et al: Alpha-interferon activates the natural killer system in patients with hairy cell leukemia. Blood 1986; 68: 293-296.

132. Faltynek CR, Princler GL, Rusetti FW, Maluish AE, Abrams $P G$, Foon KA: Relationship of the clinical response and binding of recombinant interferon alpha in patients with lymphoproliferative diseases. Blood 1986; 67: 1077-1082.

133. Samuels BL, Brownstein BH, Golomb HM: Effect of interferons on patterns of protein synthesis in hairy cells (abstr). Proc Am Assoc Cancer Res 1985; 26: 20.

134. Baldini L, Cortelezzi A, Polli N, et al: Human recombinant interferon alpha- $2 \mathrm{C}$ enhances the expression of class II HLA antigens on hairy cells. Blood 1986; 67: 458-464. 